\title{
PROFITABILITY OF CASSAVA PRODUCTION IN THE ASHANTI REGION OF GHANA
}

\author{
${ }^{1}$ Paul Okyere ${ }^{2}$ Jacqueline Baidoo \\ ${ }^{1}$ Kumasi Institute of Tropical Agriculture \\ ${ }^{2}$ University of Ghana; Department of Agriculture Economics and Agribusiness \\ 1paulokyere28@gmail.com \\ 2jacquelinebaidoo97@gmail.com
}

\begin{abstract}
Cassava is a crop that is massively produced and consumed in Ghana even though it is produced by subsistence farmers. The aim of this study is to analyse the cost and returns of cassava farmers. Farmers profitability was accessed using the gross margin, net present value and the benefit cost ratio. SWOT analysis was conducted to access challenges faced by cassava farmers. Data was collected by personal interview from fifty (50) cassava growing farmers in the Sekyere East District of the Ashanti Region, Ghana. The Costs and returns analysis show gross margin of USD 22.75 per acre. It was concluded that cassava is cultivated for both consumption and revenue. Even though there is low investment of capital in cassava production, it helps farmers to make use of available resources (personal savings, land and labour) which would have been idle. Further should compare profitability of crops that compete for use of famers land.
\end{abstract}

Keywords: Economics Feasibility, Cassava farmers' profitability, Farmers SWOT analysis, Gross margin, Cassava production challenges

(JEL Classification: Q13, Q19)

\section{INTRODUCTION}

The use of improved cassava seeds reduce poverty and increase consumption expenditure (Wossen et al., 2019). IITA/CEDP beneficiary farmers got twice the harvest of non-beneficiary farmers with the use of improved seeds (HarvestPlus, 2010). The use of improved inputs for agriculture production in the developing countries however is low. This leads to low productivity which results in low income of farmers. Adebayo et al. (2010) claim that farmers input in cassava production is low. Coupled with this is high perishability of cassava (Kwasi \& Kobina, 2014). The economic cost of cassava loss is \$300ha-1 (Danilola et al., 2019).

Farmers in Africa produce cassava to enhance food security. This might imply that farmers benefit from cassava production. It is confusing whether cassava production is for revenue (Turyagyenda et al., 2012) or for food security (Odoemenem \& Otanwa, 2011; HarvestPlus, 2010). Cassava benefit in terms of revenue and consumption is not known.

Since cassava production is on a subsistence level, investment in cassava production is crucial. The cost of input used and output realized would determine whether to invest more in cassava production or not. The question here is it is profitable for farmers to produce cassava in Ghana? The following research questions were raised. What is the profitability of cassava production? What are the opportunities and challenges in cassava production in Ghana? The study hypothesizes that cassava production 
is profitable. The work is relevant to academia due to limited studies on profitability of cassava. The paper is structured into three sections. The first section outlines the introduction. The second section explains the methodology used to address the research objective. The last section provides result and discussion.

\section{MATERIALS AND METHODS}

The study was conducted in two communities, namely, Asokore and Apemso in the Sekyere East District because it is the most dominant cassava producing district in Ghana. A total of 50 respondents were randomly selected from cassava farmer producers with the help of the Department of Agriculture in the Sekyere East District. Data was collected or obtain through primary data. Primary data was collected through interviews using structured questionnaire.

Primary data collected focused on characteristics of cassava farmers, inputs used, cassava output and their prices. Transportation, labour and pesticide are measured as kilometers, per activity on farm and kg respectively

Gross margin was used to estimate the costs and returns of cassava production in the study area. Gross margin enables the estimation of the total costs as well as total revenue accrued to the enterprise within a specific production period. The difference between revenue (returns) and Total Variable Cost (TVC) makes up the Gross Margin (GM). It evaluates the gross profitability of a given enterprise. It is useful where the value of the fixed cost is negligible as it is in the case with cassava production (Nandi et al., 2011). which is operated mostly at small scale level. Therefore, Gross Margin is given as: $\mathrm{GM}=\mathrm{TR}-\mathrm{TVC}$ (Odoemenem \& Otanwa, 2011; Nandi et al., 2011) Where, - GM = Gross Margin - TR = Total Revenue - TVC $=$ Total Variable Cost.

Discounting method which includes the net present value (NPV) and the benefit cost ratio (BCR) (Donkor et al., 2017) are used for analysis of profitability of the cassava industry. The net present value shows the cash inflows less the cash outflow within the project period. The benefit cost ratio shows the ratio of cash inflow to the cash outflow.

Assumption: Production is projected over a period of 4 years. The is because land for cassava is mostly left to fallow after four years.

Interest rate is $12 \%$. This is because most project usually uses a discount rate between 8 and 12 (Langat et al., 2015; Mensah, 2001)

\section{RESULT AND DISCUSSION}

From the 50 farmers interviewed about four fifth (78\%) had a household size of at least 4 (Table 1). This emphasis why one third of cassava output is consumed by the household as shown in Figure 1.
Table 1: Characteristics of farmers and their farms

\begin{tabular}{|c|c|c|}
\hline Variable & Frequencies & Percentage (\%) \\
\hline \multicolumn{3}{|l|}{ Household } \\
\hline $1-3$ & 11 & 22 \\
\hline $4-6$ & 18 & 36 \\
\hline $7-9$ & 15 & 30 \\
\hline More than 9 & 6 & 12 \\
\hline \multicolumn{3}{|l|}{ Land size } \\
\hline Less than 1 acre & 3 & 6 \\
\hline $1-5$ acres & 17 & 34 \\
\hline 5 acres above & 30 & 60 \\
\hline \multicolumn{3}{|l|}{ Level of education } \\
\hline None & 23 & 46 \\
\hline Primary & 9 & 18 \\
\hline JSS & 4 & 8 \\
\hline Senior high & 2 & 4 \\
\hline Tertiary & 2 & 4 \\
\hline \multicolumn{3}{|l|}{ Farming experience } \\
\hline $1-5$ & 7 & 14 \\
\hline $6-10$ & 9 & 18 \\
\hline $11-15$ & 11 & 22 \\
\hline $16-20$ & 11 & 22 \\
\hline More than 20 & 12 & 24 \\
\hline \multicolumn{3}{|l|}{ Use of labour hired } \\
\hline Yes & 40 & 80 \\
\hline No & 10 & 20 \\
\hline \multicolumn{3}{|l|}{ Land arrangement } \\
\hline Inheritance & 42 & 84 \\
\hline sharecropping & 5 & 10 \\
\hline Renting & 3 & 6 \\
\hline \multicolumn{3}{|l|}{$\begin{array}{l}\text { Food crop production } \\
\text { (in acres) }\end{array}$} \\
\hline Land under cassava & 16 & 32 \\
\hline Land under maize & 9 & 18 \\
\hline Land under plantain & 11 & 22 \\
\hline Land under cocoyam & 9 & 18 \\
\hline Land under yam & 5 & 10 \\
\hline
\end{tabular}

More than half of farmers $(60 \%)$ have at least five acres of land which is about two hectares (Table 1). This land is usually inherited. Land is used for a combination of crops of which cassava takes about one third of land use. This means that majority of farmers land is used for cassava cultivation explaining the importance of cassava to farmers. About half of farmers (46\%) have no formal education but more than four fifth of farmers (86\%) have more than five year of farming experience (Table 1). This might explain why farmers skills depend on low input for farming. About $80 \%$ of farmers hire labour on their farms (Table 1).

\section{Use of cassava tubers}

An acre of land yield about $6000 \mathrm{~kg}$ of cassava. The two major use of cassava is for sale (45\%) and consumption (34\%) (Table 1). 
Figure 1: Percentage of use of cassava

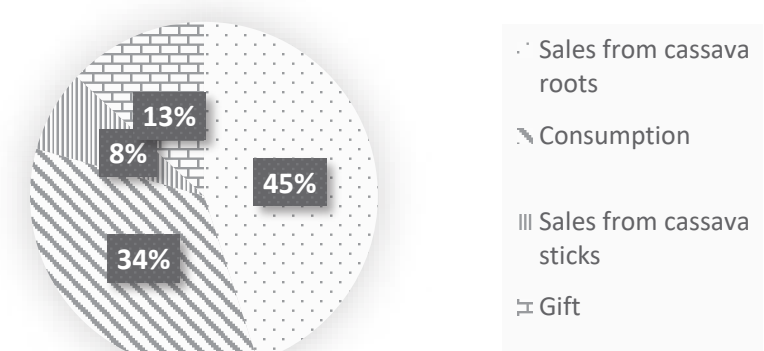

Cassava serves as a food security crop as almost half of cassava (47\%) is used for consumption and gift. From Figure 1, about half $(45 \%)$ of cassava is sold for revenue. This implies that increase in production of cassava would increase revenue gotten. More than a third (34\%) of cassava is consumed by farmers. Cassava serves as a food security as more than a third (34\%) of cassava production is consumed. This finding is in conformity to the findings of Gaffney et al. (2012) that cassava is a famine resilient crop. This is also in agreement with the findings that cassava is a dominant staple crop (Masamha et al. 2017).

\subsection{Profitability of cassava Production}

The cost structure of cassava production is viewed in terms of activities indicating how much the farmer spends. In analysing the cost structure of cassava production in terms of activities, four major activities were identified namely; transportation, labour and pesticide. Labour cost includes money paid to labour to perform activities such as planting, weeding and harvesting of cassava roots. Expenditure on tools (hoes, cutlasses, baskets and sacks) was as low at USD 50.05, representing $13.0 \%$ of total cost (Table 2).

Table 2: Gross margin of cassava production

\begin{tabular}{|l|l|l|}
\hline \multicolumn{1}{l}{ USD } \\
\begin{tabular}{|l|l|} 
Total Variable cost per acre of \\
land
\end{tabular} & \multicolumn{2}{l}{} \\
\hline Transportation & 86.45 & 22.6 \\
\hline $\begin{array}{l}\text { Labour (both hired and family } \\
\text { labour) }\end{array}$ & 200.2 & 52.3 \\
\hline Pesticide & 45.5 & 11.9 \\
\hline tools cost & 50.05 & 13.0 \\
\hline Total Variable Cost & 382.2 & 100 \\
\hline Revenue per acre & & \\
\hline Sales from cassava roots & 345.8 & 85.4 \\
\hline Sales from cassava sticks & 59.15 & 14.6 \\
\hline Total revenue & 404.95 & 100 \\
\hline Gross margin & USD404.95 - & USD382.2 = \\
\hline
\end{tabular}

Labour cost shared the highest amount (35.7\%) among total cost (Table 2). Labour is usually used for the performance of agronomic practices and harvesting cassava (Masamha et al. 2017). Labour cost is followed by transportation cost accounting for about $(22.6 \%)$ of the total production cost (Table 2). Inadequate investment in technologies is dominant in cassava production which if rectified might lead to a double increase in productivity.

The Costs and returns analysis show gross margin of USD 22.75 per acre (Table 2). This means that a farmer get 22.75 Ghana cedis at the end of the year. After four years when the land is allowed to fallow, a farmer gets USD 77.40 (Table 3)

Table 3: Financial analysis of cassava production

\begin{tabular}{|l|c|c|c|c|c|c|}
\hline & Year & $\begin{array}{l}\text { Cash } \\
\text { outflow }\end{array}$ & $\begin{array}{l}\text { Cash } \\
\text { inflow }\end{array}$ & $\begin{array}{l}12 \% \\
\text { Discount } \\
\text { factor }\end{array}$ & $\begin{array}{l}\text { Dis- } \\
\text { counted } \\
\text { Cash } \\
\text { inflow }\end{array}$ & $\begin{array}{l}\text { Dis- } \\
\text { counted } \\
\text { Cash } \\
\text { outflow }\end{array}$ \\
\hline 1 & 2019 & 382.2 & 404.95 & 1.00 & 404.95 & 382.20 \\
\hline 2 & 2020 & 382.2 & 404.95 & 0.89 & 361.62 & 341.30 \\
\hline 3 & 2021 & 382.2 & 404.95 & 0.80 & 322.75 & 304.61 \\
\hline 4 & 2022 & 382.2 & 404.95 & 0.71 & 288.32 & 272.13 \\
\hline & Total & & & & 1377.64 & 1300.24 \\
\hline \multicolumn{7}{|c}{} \\
\hline
\end{tabular}

A USD 1 invested into the cassava industry gives USD 1.06 at the end of four years.

\section{SWOT analysis of cassava farmers}

The SWOT is viewed according to their strength, weakness, and opportunity and threats. The results in Table 4 are ranked according to their importance. Considering the SWOT, the results show that a farmer exemplifies many prospects, and has his strength and weaknesses. Their main strength is their personal savings and high market penetration (Table 4). With regard to resources, cassava farmers have available land and labour.

Table 4: SWOT Analysis of the Respondents

\begin{tabular}{|l|l|}
\hline \multicolumn{1}{|c|}{ STRENGTHS } & \multicolumn{1}{c|}{ WEAKNESS } \\
\hline Have personal savings to invest & Low cash flows \\
\hline High market penetration & Low investment in resources \\
\hline $\begin{array}{l}\text { Land is freely given through } \\
\text { inheritance }\end{array}$ & Low bargaining power of farmers \\
\hline Availability of labour & $\begin{array}{l}\text { Lack of accounting and other soft } \\
\text { skills due to low level of education }\end{array}$ \\
\hline OPORTITIES & THREATS \\
\hline $\begin{array}{l}\text { Cassava is regarded as a hunger } \\
\text { security crop because of the 1983 } \\
\text { hunger }\end{array}$ & Government less concern \\
\hline
\end{tabular}


Farmers weakness of low accounting and soft skills and low bargaining power (Table 4) can be traced to their low level of formal education (Table 1). Farmers can use their high market penetration to increase their bargaining power by forming co-operatives. Cassava farmers had many opportunities as regard to their cassava production. The 1983 hunger in Ghana has revealed the importance of cassava as a resistant crop in Ghana. Ghanaians have thus developed a taste for cassava and its products. Cassava is periodically demanded by consumers. This has increased the involvement of donors in supporting cassava production. This conforms with findings that donors play a critical role in supporting the cassava value chain (Poku et al.2018).

Cassava farmers had threat of less concern of government in cassava production (Table 4). Formation of co-operatives by farmers would increase their visibility to government.

\section{CONCLUSION}

From this research, it can be concluded that cassava is cultivated for both consumption and revenue. Even though there is low investment of capital in cassava production, it helps farmers to make use of available resources (personal savings, land and labour) which would have been idle. Further studies should compare profitability of crops that compete for use of famers land.

\section{REFERENCES}

Adebayo, K., Abayomi, L., Abass, A., Dziedzoave, N. T., Forsythe, L., Hillocks, R. J., Gensi, R., Gibson, R. W., Graffham, A. J., Ilona, P., Kleih, U. K., Lamboll, R. I., Mahende, G., Martin, A. M, Onumah, G. E., Orr, A. W., Posthumus, H., Sanni, L. O., Sandifolo, V., and Westby, A (2010). Sustainable Inclusion of Smallholders in the Emerging High Quality Cassava Flour Value Chains in Africa: Challenges for Agricultural Extension Services. Journal of Agricultural Extension. 14 (1) $1-10$

Danilola S.T., Babatunde R., Animashaun J. (2019). Extent and financial cost of cassava postharvest loss along the cassava value chain in Kwara State, Nigeria. Acta Agriculturae Slovenica. 114(2)149-155

Donkor E., Owusu-Sekyere E., Owusu V., Saadu S., Baidoo J., Avame H. Y., Djamson E. K., \& Serbeh F.O., (2017) Assessing the financial viability of the floricultural industry in Ghana. APSTRACT. DOI: 10.19041/APSTRACT/2017/1-2/15

Gaffney, A. Kpaka, K., Slakie, E., and Anderson, L. (2012). Cassava Integrated Value Chain. Evans School Policy Analysis and Research (EPAR). (Brief No. 223). Retrieved from: https://evans.uw.edu/sites/default/files/public/EPAR_UW_Request_223_Cassava_Integrated_Value_Chain_Public_Version_03.05.13_af.pdf
HarvestPlus (2010). Provitamin A Cassava in the Democratic Republic of Congo: Country Crop Profile. Retrieved from: https://www.harvestplus.org/sites/default/files/CCP\%20DRC\%20 Cassava_final_0.pdf

Kwasi, B. R., \& Kobina, B. J. (2014). Cassava markets integration analysis in the central region of Ghana. Indian Journal of Economics and Development, 10(4), 319-329

Langat D. K., Cheboiwo J. K. and Muchiri M. N. (2015). Financial analysis of growing Eucalyptus grandis for production of medium-size power transmission poles and firewood in Kenya. African Journal of Agriculture and Utilisation of Natural Resources for Sustainable Development 1 (1): 38-45

Masamha, B. Thebe, V. and Uzokwe V. N.E. (2017) Mapping cassava food value chains in Tanzania's smallholder farming sector: The implications of intra-household gender dynamics. Journal of Rural Studies. 58 (2018) 82-92

Mensah, K.B. (2001). Economics of Cocoa-Agroforest in the Gwira Banso Joint Forest Management Project in Western Region of Ghana. University of Ghana

Nandi, J. A., Gunn, P., \& Yurkushi, E. N. (2011). Economic Analysis of Cassava Production in Obubra Local Government Area of Cross River State, Nigeria. Asian Journal of Agricultural Sciences, 3(3), 205-209.

Odoemenem, I. U., \& Otanwa, L. B. (2011). Economic analysis of cassava production in Benue State, Nigeria. Current Research Journal of Social Sciences, 3(5), 406-411.

Poku, A., Birner, R. and Gupta, S. (2018). Is Africa ready to develop a competitive bio economy? The case of the cassava value web in Ghana. Journal of Cleaner Production 200 (2018) 134-147 https://www.sciencedirect.com/science/article/pii/ S0959652618322790.

Turyagyenda. G., Iyangbe, C., Udensi, U. E., Ilona, P., Osun, T., Okater, C. and Asumugha, G. N. (2012). Commercial-scale adoption of improved cassava varieties: A baseline study to highlight constraints of large-scale cassava based agro-processing industries in Southern Nigeria. Journal of Food, Agriculture and Environment, 10(3\&4):680-688

Wossen T., Alene A., Abdoulaye T., Feleke S., Rabbi I.Y., Manyong V. (2019). Poverty Reduction Effects of Agricultural Technology Adoption: The Case of Improved Cassava Varieties in Nigeria. Journal of Agricultural Economics. 70(2)392-407 